\title{
Notes on the Culture of some Marine Plankton Organisms.
}

\author{
By \\ F. Gross, \\ Marine Biological Laboratory, Plymouth.
}

In recent years considerable advance has been made in the methods for culturing marine organisms. We are still unable to dispense with seawater as the main component of the culture medium, and in this respect, in spite of some notable efforts (Allen, 1914), the methods are less satisfactory than those developed for many freshwater organisms and based on synthetic media (Hartmann, 1928; Belar, 1928; Pringsheim, 1924). But the application of certain standards of purity and sterility in medium, culture dishes and instruments to culture work on marine organisms (Allen and Nelson, 1910), the enrichment of sterilized sea-water with certain nutrient salts (Allen's modification of Miquel, Schreiber), and more recently the development of the "Erdschreiber" as a culture medium (Föyn, 1934) have made possible the culture of an increasing variety of marine protozoa, algae and small invertebrates. In the last-mentioned medium Föyn cultured the algae Ulva and Cladophora, and Hämmerling (1934) two species of Acetabularia through several generations; the present author used it for Artemia, the brine shrimp (1932), and for Noctiluca (1934); Hartmann and Huth (1936) for Ophryotrocha, Shen (1936) for Dinophilus and Rühmekorf (1935) for a hypotrych ciliate, Keronopsis. Growing Ulva and Cladophora from parthenogametes of a single plant in six different media, under otherwise very similar conditions, Föyn showed that the media could be arranged in the following order of quality : pure sea-water $\longrightarrow$ Schreiber's medium $\longrightarrow$ Allen's medium $\longrightarrow$ Killian's medium $\longrightarrow$ sea-water + soil extract $\longrightarrow$ " Erdschreiber."

Since autumn, 1935, I have been studying chiefly the life-histories of certain plankton diatoms, an account of which will be published elsewhere. In the following pages a short description is given of the culture technique developed for the centric diatoms which may be of some value for future investigators. Notes on the culture of certain other plankton organisms are included, and on attempts to rear fish larvae which failed but gave some indication of how such rearing might in future be undertaken with more success. 


\section{Culture Methods for Diatoms.}

Föyn's "Erdschreiber" is a combination of Schreiber's medium (Schreiber, 1927) and soil extract, which has been used before for the culture of freshwater algae (Pringsheim, 1924). It consists of :-

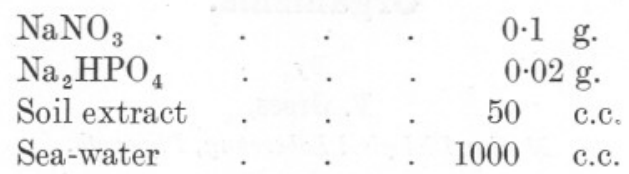

The soil extract is made up by boiling for one hour $1 \mathrm{~kg}$. of good garden or potting soil with 1 litre glass distilled water in an autoclave. (More recently $I$ have been using tap water with equal success.) After 2-3 days the resulting brown and rather dirty fluid is decanted into a flask and sterilized by heating up to the boiling point. After standing for 3-4 weeks the rougher particles settle to the bottom and the fluid becomes transparent, brown or red in colour and ready for use. If mould or bacteria develop in the meantime it must be sterilized again. In any case, repeated decanting and boiling enhances the process of clarifying the fluid. Before use the soil extract is poured into another flask and boiled for a short time ; the required amounts of nitrate and phosphate are then dissolved in it and sterile sea-water added. If large quantities of culture medium are needed at short intervals one or more litres of soil extract with the nitrate and phosphate already dissolved can be kept in stock, and the culture medium quickly made up with sea-water before use. It is advisable to keep the stock solution in a refrigerator and to avoid boiling the soil extract once the salts had been added.

Throughout the work "outside" sea-water* has been used. It was first filtered through filter paper (Whatman No. 1) and then heated to boiling point. Since boiling produces some physico-chemical changes it is advisable to allow this water to stand for 3-4 weeks before use. During this period the sea-water recovers its normal $\mathrm{O}_{2}$ and $\mathrm{CO}_{2}$ content and the $\mathrm{pH}$ returns to its normal value (Schreiber, 1927). If no old sterile seawater is available fresh sea-water should be filtered and heated only to $70^{\circ} \mathrm{C}$. The flasks with soil extract, sea-water and culture medium should be closed with overlapping glass capsules. Paper bound with string round the top and neck of the flasks is useful for keeping the dust off the glass capsules.

Small watch glasses, $5 \mathrm{~cm}$. in diameter, with ground edges, containing about 2 c.c. of fluid and covered with round glass plates, and Petri-dishes

* At Plymouth the water from the Sound or in the Aquarium circulation is too contaminated for delicate organisms and water is therefore collected in the open sea well outside the Breakwater ; this is called "outside" sea-water. 
about $10 \mathrm{~cm}$. in diameter, were used as culture dishes. These as well as the flasks for sea-water and culture medium, the glass capsules and pipette tubes-in short, all glass ware for culture purposes-were first cleaned by being either put into or filled with a mixture of sulphuric acid-bichromate for several hours. Then they were thoroughly rinsed with tap water and finally the smaller glass ware was boiled in a porcelain dish with glass distilled water, and the flasks filled with a small amount of distilled water and boiled over the gas burner.

The greatest difficulty confronting the culturing of marine unicellular algae is to start the culture free from flagellates and bacteria. Allen and Nelson (1910) often succeeded by diluting a small quantity of a plankton sample containing diatoms, or colonies of a species developed in a raw culture, in a large quantity of culture fluid and subdividing it into a number of culture flasks. Schreiber used a special apparatus, the "plankton purifier."

In my own experience the direct method, that is the isolation of a few or single cells from a plankton sample, gave quick and satisfactory results. The diatoms were isolated under a low-power binocular dissecting microscope from catches with a very fine silk tow-net. This dissecting microscope is the most important piece of apparatus for culture work. Even for the smallest plankton diatoms the combination of the eyepieces $\times 8$ and the objectives $\times 3, \times 4$ and $\times 8$ gives a range of magnifications sufficient not only for isolation, washing and subculturing of the cells, but also for the study of the division rate, and control of the general health of the diatoms, of the appearance of resting-spores or auxospores, and even of the presence of infections by very small flagellates. It is only for ensuring purity from bacteria that one has to use the high-power microscope.

The diatoms were picked out singly with fine pipettes. It is important to take the cells out with as little fluid as possible to avoid contamination. For this purpose the fine end of the pipette should be long (about $5 \mathrm{~cm}$.) and of a more or less uniform diameter with an opening not exceeding twice or three times the diameter of the cell to be isolated. The cell drawn into the pipette is then squirted sharply* into a watch glass with 1-2 c.c. of sterile culture medium. If left in this watch glass for a few days the cell might divide and give rise to a colony, but small flagellates would almost invariably develop and eventually overgrow the diatoms completely. It is therefore essential to wash the isolated cells by passing them through a further 2 or 3 sterile water samples in watch glasses. Working with the lowest possible magnification it does not take long to find a single diatom cell in a volume of 1-2 c.c. of water. Next day if the

* In my experience only Rhizosolenia robusta is liable to be caught by the surface film and has therefore to be transferred very gently. 
diatoms are in a healthy state they have either divided or grown in size or are suspended in the water, in short, they show a definite improvement as compared with their usually lethargic state in the overcrowded townettings. The washing is repeated once or twice and the cells left for a few days in a watch glass, well covered with a glass plate. If they reproduce satisfactorily a sample may be washed after a week or so and transferred into a Petri-dish. In spite of a good initial growth of the diatoms the subsequent cultures must be carefully watched for the presence of small flagellates. The reproduction of these may at the beginning be inhibited by the growth of the diatoms, particularly if the light and temperature conditions are very favourable for the diatoms. However, after some weeks or even months the growth of the diatoms may stop and on careful examination one may find enormous numbers of flagellates of a size of $2-6 \mu$.

Before every operation involving the transference of diatoms from one culture dish into another-isolation, washing, subculturing-the pipette should be sterilized by dipping it into boiling glass-distilled water in a beaker and afterwards cooled in sterile culture medium. This is necessary in order to avoid contamination and to clean the pipette.

The cultures were kept at room temperature and placed near a window facing north. During the winter months a 100 -w. lamp hanging at a distance of about $1 \mathrm{~m}$. was used to increase the illumination during the day. In summer the cultures of Coscinodiscus Granii grew better in a dim light at a distance of $2-3 \mathrm{~m}$. from the north window.

Subcultures were made every two to three weeks and inoculated mostly with 10-100 cells. In spring and summer subcultures of rapidly growing forms like Ditylium, Chaetoceros, Skeletonema and Melosira had to be made at shorter intervals. It is advisable to keep the old cultures for some time because, for reasons mostly unknown, not all subcultures are equally successful. I had several times to return to 4 - to 6 -weeks old cultures, and then a sample of these old cells was passed at intervals of 1-2 days through a number of watch glasses before inoculating a Petri-dish. Washing the cells to be transferred is also necessary when cultures contain bacteria.

Bacteria-free cultures were not aimed at and no special bacteria tests made. They correspond to Allen's " persistent" cultures, or what are generally called "pure cultures," containing only harmless bacteria besides the one cultured species of protozoa, in contrast to "absolutely pure" or bacteria-free cultures. Since the cultures were frequently examined and a large surface of the watch glasses and Petri-dishes was thus exposed to the air, the occasional appearance of mostly harmless bacteria was to be expected. However, from my experience it seems very probable that with the same methods, but using culture flasks or test 
tubes instead of Petri-dishes, one could easily get continuous cultures of absolute purity.

It may be mentioned that in January and February, 1936, after having grown extremely well for three months, the cultures of Ditylium gave some trouble by producing numerous cells with slightly contracted and highly refractive protoplasts. The division rate was also very much reduced and it became difficult to make new subcultures. Eventually the difficulties were overcome by adding traces of $\mathrm{CuSO}_{4}$ to the culture medium. The pipette was dipped into a m. 10,000 solution of $\mathrm{CuSO}_{4}$ and washed off in the Petri-dish prepared for the subculture. Previously similar traces of $\mathrm{Cu}$ were introduced by using for the sterilization of pipettes porcelain-distilled (instead of glass-distilled) water which according to tests made by Dr. L. H. N. Cooper contained definite traces of copper. This might be interpreted as showing that in winter, and probably also in autumn, sea-water contains too little copper, or none at all, which must therefore be added to the culture medium, while in spring there is a sufficient supply of it in sea-water. However, although from January until March many cultures without the addition of $\mathrm{CuSO}_{4}$ were not successful, whereas those supplied with traces of it showed excellent growth, I would hesitate to regard copper as an essential part of the culture medium without more elaborate and controlled experiments. There might have been small numbers of bacteria present the effect of which was checked by $\mathrm{CuSO}_{4}$.

The following diatom species were obtained in pure cultures.*

Biddulphia mobiliensis (Bail.) Grun.

Chaetoceros didymus Ehr.

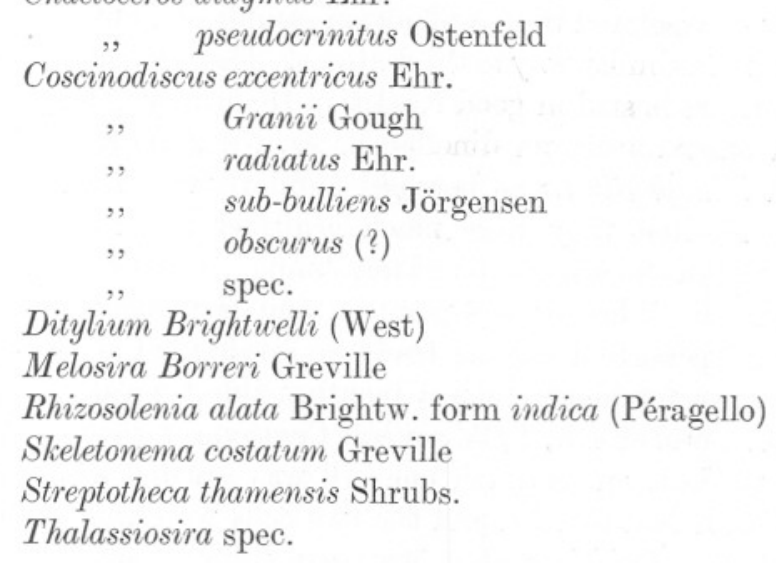

This list includes only those species which were cultured for at least three months through several subcultures - some are now 16 months old.

* Most of the diatoms cultured were kindly identified by Dr. Marie V. Lebour. 
Some others have been cultured for shorter periods and abandoned because there were too many cultures to be cared for. It was, however, reasonably certain that under the conditions given they could have been kept for much longer periods. These species were :

\author{
Chaetoceros borealis. \\ ,, gracilis. \\ Eucampia zoodiacum. \\ Lauderia borealis. \\ Rhizosolenia Shrubsolei (?).
}

Cultures of Biddulphia regia and B. sinensis were not very successful. For short periods of about 4 weeks they divided quite actively. But after that the growth stopped, their shape becoming slightly abnormal and their chromatophores dark brown.

The methods described above were definitely inadequate for Corethron criophilum and Hyalodiscus stelliger. Although I tried repeatedly, not more than one division took place in isolated Corethron cells and none in Hyalodiscus. The cells of the first species looked extremely healthy the first few days after isolation into " Erdschreiber," being freely suspended in the water, but afterwards the protoplast disintegrated.

\title{
The Culturing of Other Organisms.
}

\section{Dinoflagellates.}

The culture methods described above were tried out on some plankton dinoflagellates. Only the culture of Prorocentrum micans was successful. Two cells were isolated from a plankton sample on September 27th, 1935, and treated in a similar way to the diatoms. They reproduced very quickly and the culture is still in good condition (February, 1937).

Certain other autotroph dinoflagellates, Ceratium tripos, C. fusus, C. furca and Dinophysis tripos behaved similarly to Corethron among the diatoms. At first they were much healthier and moved about more actively than in the original plankton sample. One or two divisions took place, with the subsequent separation and restitution of the daughter cells, but no persistent culture could be established although some cells remained alive for longer than a month. One typical example may be given. On October 4th, 1935, several Ceratium tripos were isolated and carefully washed, on the 17th one cell was isolated and washed again. By the 24th it had divided and the two cells were then transferred into fresh medium. On November 5th there were seven cells; these were washed twice. On the 8 th there were only six alive; they were washed three times. On the 12th six were transferred and of these on the 18th four were alive, which were washed once. On the 22 nd only one was alive 
and very active. This Ceratium was alive on the 23rd and 24th and was transferred each day but by the 30th it had died.

Whatever the reason for the inhibition of their division may have been, it was certainly not caused by the presence of any contaminating organisms, flagellates or bacteria.

Some colourless and probably saprophytic species could be kept alive for some time, Peridinium depressum for nearly 4 weeks, and two specimens of Peridiniopsis spec. for six weeks. The latter "moulted " after about five weeks, abandoning the old shells and forming new ones, a process which also occurs often in overcrowded cultures of Prorocentrum.

\section{Nannoplankton flagellates.}

My attempts to obtain pure cultures of diatoms and dinoflagellates drew my attention to a big and varied group of autotroph nannoplankton flagellates, most of them probably unknown systematically.

If a diatom or a dinoflagellate is picked out from a plankton sample with only a tiny drop of the original medium and transferred into a watch glass with " Erdschreiber," one will almost regularly obtain the growth of one or more species of flagellates rather than that of the diatom or dinoflagellate. If these are passed through one or two watch glasses with sterile medium whereby the original drop of plankton fluid is diluted to 2-4 c.c. one may still obtain a flagellate culture, but it is more likely that it will be a pure culture of one species only. From their presence in diatom cultures started in the way just described it may be concluded that almost every drop of plankton fluid contains one or more flagellates.

By that very indirect method I obtained within several weeks cultures of about a dozen flagellates which were - and some are still-kept in 100 c.c. culture flasks with about 50 c.c. of "Erdschreiber" and subcultured every $3-5$ weeks. No special study has been made of them so far. In size they range from less than $2 \mu$ to $10 \mu$. The colour of the chromatophores and of the cultures respectively is opaque-green, green, brown and yellow-brown. The movement is characteristic in some species. In one flagellate the periods of movement and of rest, i.e. free suspension in the water, follow each other at varying intervals, the movement starting and stopping with extreme suddenness. Most of the flagellates probably belong to the Chrysophyceae and Cryptophyceae, and a few to the Volvocales.

Once I had gained some experience with regard to their size, shape and movement these tiny flagellates could be found in every sample of townettings examined. Under the binocular, eyepiece $\times 8$, objective $\times 8$, one can see them distinctly down to a size of about $4 \mu$, and under favourable light conditions even those $2 \mu$ in size. By the use of the dissecting 
microscope with its wide field one gets a better, if only a very general, idea of their number and variety than by isolating drops of plankton fluid and examining them under a high power. They appear to be more numerous in spring, summer and autumn than during winter. They were often present in fair numbers in tow-nettings which were extremely poor in diatoms and other phytoplankton. During the autumn and winter of 1935-6 single drops of plankton fluid were occasionally placed in watch glasses with culture medium and invariably gave growth to mostly mixed cultures of flagellates.

The technique of isolating and washing single cells of diatoms cannot be applied to these organisms. It is very difficult to handle objects less than $12 \mu$ in size in that way. The isolation is possible, but not the washing in watch glasses because of the difficulty of finding the isolated object again. The dilution method as used by Allen (1910) seemed to be the appropriate one and was tried out with success. One picks out under the binocular what one believes to be a single flagellate-in fact there will probably be two or more specimens in the drop of water drawn into the pipette-and places the drop in 1 c.c. of medium. This is distributed over 5-10 culture flasks and if successful one or the other flask may give a pure culture of a flagellate. If a culture contains two species of flagellates they sometimes will not reproduce at the same rate, but one will have its flowering period after the other. The culture may, for instance, take a more and more intensive golden-yellow colour owing to the growth of one type, then this colour may fade away in a day or two and give way to the green tint of the second flagellate. By repeated subculturing at the right time one can sometimes succeed in gradually separating the two species or eliminating one. The use of solid media would probably give better and quicker results (see Alvik, 1934).

Some of the flagellates cultured were tried out as food for various larvae. A harpacticid copepod has been cultured for three generations. The adults, about $1 \mathrm{~mm}$. in length, could be fed on flagellates $12 \mu$ in size. Newly hatched nauplii died on this diet but lived very well on flagellates of $5-7 \mu$. Several polychaete larvae could be observed taking them in, as could plankton copepods. The latter could not be kept longer than 3-4 weeks, but the cause of their death was probably not lack of or inadequacy of food (see p. 765).

All these experiments led me to the conclusion that the autotroph nannoplankton flagellates are of great importance in the food economy of the sea. The bulk of living matter provided by them is probably much smaller than that of diatoms and dinoflagellates, although the proportion in which they appear in tow-nettings certainly is misleading, since flagellates of $2-10 \mu$ are not retained in the net to the same extent as the bigger phytoplankton. But their reproduction is more rapid and they are 
of the right size to be taken in by the filter-feeding organisms, and are far more numerous and more often present in the plankton than small pennate diatoms of the type of Nitzschia closterium var. minutissima, cultured by Dr. E. J. Allen and successfully used by him and his collaborators in rearing various marine larvae.

Some of the minute algae mentioned above are probably related to or i dentical with those found in Norwegian oyster pools and investigated by Alvik (1934). This author obtained pure cultures of six algae which he described as new species. Previous to this work it has been shown by Gaarder (1933) that oysters and their larvae need green algae of $2-3 \mu$ as food.

From studies of the plankton of tanks at Conway with enriched seawater where a good settlement of oyster larvae took place, and of tanks with untreated sea-water where few larvae or none settled, Mr. H. A. Cole (private communication) arrived at a similar conclusion to the Norwegian author (Gaarder, 1933), namely, that nanno-plankton flagellates of a size of $7 \mu$ and less are suitable food for oyster larvae.

The whole group of nannoplankton flagellates certainly deserves further investigation along the same lines as those for larger plankton organisms, i.e. systematics, life-history, distribution in the sea, abundance in different seasons, requirements with regard to nutrients, light and other factors governing the life in the sea. An important start has been made by Gaarder (1932), Gaarder and Spärck (1932) and Ålvik (1934) with their studies on Norwegian oyster pools.

\section{Larvae.}

To get an idea of the efficiency of "Erdschreiber" as a culture medium larvae were picked out occasionally from the plankton and attempts made to rear them. A Pilidium larva (of a nemertine) was isolated on October 17th, 1935, and transferred every few days into a watch glass with fresh medium and Chlamydomonas spec.* as food. This was taken in readily and on November 1st metamorphosis took place. It was very interesting to note that after the release of the young worm the "larva," not much changed in its external appearance, continued swimming about very actively, with the apical sensory hair in slight motion as before. It was alive and active on the 7th but reduced in size and irregular in shape. On the 13th it had disappeared.

On October 1st, 1935, Dr. Allen kindly gave me a Phoronis larva which he had found in a plankton sample. It was placed in "Erdschreiber" with Chlamydomonas as food. The larva started feeding immediately

* This has been used before as food for Artemia salina and Noctiluca miliaris (Gross, 1932, 34). 
and the algae were driven into the oesophagus and after some time passed into the gut. Here they were kept moving round, towards the oesophagus on the dorsal side, posteriorly on the ventral. After half an hour there were a great number of Chlamydomonas in the gut and its fluid was green. However, the next and the following days very few were taken in and the larva, particularly its tentacles, became gradually reduced in size. The larva remained alive until the 26th.

Oikopleura larvae were isolated several times and provided with flagellates of various sizes but always died within 24 hours.

\section{Herring.}

The larvae were reared from eggs which had been artificially fertilized* on January 21st, 1936. They hatched on the 31st and on February 1st respectively and 120 larvae were kept in groups of 4-10 in finger-bowls at conditions varied with regard to medium, food and temperature. The following media were tried: "outside" sea-water unsterilized, sterilized by heating to $60^{\circ}, 70^{\circ}$ and $100^{\circ} \mathrm{C}$., Allen's modification of Miquel, and "Erdschreiber" with varying amounts of soil-extract. As food were offered: Chlamydomonas spec., Prorocentrum micans, Thalassiosira spec., Coscinodiscus radiatus and Skeletonema costatum. The cultures were kept at room temperature (reaching $17^{\circ} \mathrm{C}$. during the day, dropping to $8-11^{\circ}$ at night), on a window-sill on a landing (with a lower day-maximum of about $12-13^{\circ}$ ) and in containers with running tap water $\left(9-12^{\circ}\right)$.

The yolk sac was absorbed after 6-8 days in all larvae except in those kept under running tap water where most larvae retained it as long as 13 days. Until the yolk sac had gone the mortality was negligible, after that it increased considerably. The majority of the larvae were alive 10 days after the yolk sac had been exhausted, some survived until the 19th-24.th at room temperature, and until the 27th in cultures kept under running tap water.

There was no obvious difference in the viability of the larvae kept in different media. Chlamydomonas and Prorocentrum could be seen inside the gut in many larvae soon after the yolk sac had been absorbed, but Thalassiosira only in one larva. The other diatoms were probably too big. Chlamydomonas was sometimes taken in in large masses, so that the gut could be seen as a green line with the naked eye. Some larvae were watched extruding faecal pellets consisting of remnants of Chlamydomonas and to a far lesser extent Prorocentrum.

Lack of food can therefore not have been the cause of their death. That the food offered was inadequate is not likely since Prorocentrum represents an important item of the diet of young herrings (7-12 mm.) in

\footnotetext{
* I am indebted to Mr. E. Ford who performed the artificial fertilization.
} 
nature (Hardy, 1924). What else could be the reason for the failure in rearing herring larvae?

Some incidental experiments may be recorded which throw some light on this problem. The larvae-following the ordinary routine in culturing -were transferred to finger-bowls with fresh medium and food every 5-7 days, sometimes at shorter intervals so as to avoid any harmful effects of accumulating metabolic products. However, a very puzzling result was often obtained, the larvae dying a few hours after the transference. At first I thought that they had been damaged by handling them with too narrow pipettes. I then used bigger ones and finally small finger bowls as a kind of spoon with which I transferred the larvae. But the effect remained the same. One instance may be given with more details. A culture of 15 larvae was kept from January 8th till the 13th on the laboratory landing in pure sea-water and all the animals were very healthy during that period. On the 13 th seven larvae were taken out with a broad pipette and placed in fresh sea-water from the same bottle as on the 8 th. Half an hour later six larvae were lying at the bottom of the bowl, opaque in colour and very weak. Three hours later three larvae were dead, the next day three more, while the last larva fed on Chlamydomonas and survived until the 20th. The herrings which had been left in the old sea-water on the 13th remained very healthy until the 19th when they were cautiously transferred into fresh sea-water + food. Fifteen minutes later four animals were dead, lying at the surface of the water with the body bent abnormally, the brain opaque and the fins broken. A further two larvae died the following day. Similarly several larvae kept under running tap water were killed when transferred into fresh medium.

The explanation may be found in the fact that the stock of sea-water kept in the room was of a temperature several degrees higher than the old medium kept on the landing and under running tap water, and that the sudden change of temperature proved fatal even in such a short time.

\section{Angler-fish.}

On March 25th, 1936, a piece of spawn of Lophius was brought in by S.S. Salpa. Most of the larvae were hatched and were moving about in the capsules. They were liberated by deliberate cutting with a pair of scissors through the gelatinous ribbon in which they were embedded* and placed in small tanks and finger bowls with the same media as the herrings. Some cultures were kept in an unheated cellar where the temperature varied fiom 12 to $14 \cdot 5^{\circ}$, i.e. much less than in the laboratory-rooms, others in a bath with running tap water of a temperature varying between 10.5

* If left in it most larvae will hatch out into the water, but an enormous growth of bacteria takes place. 
and $12^{\circ}$. The yolk sac was absorbed between April 10th and 14th. Prorocentrum, small copepods and cladocera from the plankton and newly hatched nauplii of Artemia salina were offered as food. I have only noticed that Artemia nauplii were taken in by the young anglers. On the 15th only three larvae out of 200 kept in the cellar had survived, but 45 out of 150 kept under running water. Of the latter 12 were alive and very lively on the 20 th, and 5 on the 21 st. They died on the 23 rd.

\section{Pilchard.}

Larvae of Sardina pilchardus were obtained from eggs brought in by S.S. Salpa from Station E2 on May 12th. Sixty larvae hatched on the 14th and were kept in the cellar in finger bowls standing in a tank with running tap water. The temperature of the tank water varied from 13.5 to $14.5^{\circ} \mathrm{C}$. The media used were sterile sea-water and " Erdschreiber." On the 19th almost all larvae had their yolk sac absorbed; on the 22 nd they were seen feeding actively and their guts contained masses of Chlamydomonas and smaller numbers of Prorocentrum. Five larvae were placed in another finger bowl and taken to the main laboratory to show them to some colleagues. They were brought back after about 10 minutes and 20 minutes later 3 were dead and 2 very weak. As the rest of the Pilchards in the original dish were in perfect health the cause for their sudden death could only have been the increase of temperature for 10 minutes.

\section{Discussion.}

The preceding account affords an opportunity for discussing the problem why some plankton organisms can be cultured or reared and others not. The methods adopted for culturing diatoms were adequate for quite a number of them. Adding to the list given on pp. 757-58 some more which had been cultured by Allen and Nelson-Asterionella japonica, Chaetoceros densum, C. decipiens, C. constrictum, Cocconeis scutellum, Nitzschia closterium, N. seriata, Rhizosolenia stolterfothi, to mention only those species not represented on my list-one obtains a very representative selection of most diatom groups present in the plankton off Plymouth. It is all the more peculiar that two species, Corethron criophilum and Hyalodiscus stelliger, have resisted every attempt to culture them. It appears to me unlikely that these two species should require a medium fundamentally different from that in which there was an excellent growth of the other diatoms all the year round, or that species of Ceratium should need a medium different from that suitable for Prorocentrum and Noctiluca, or an Oikopleura larva a medium different from that of a Pilidium larva. It seems more probable that the temperature of the 
Laboratory rooms, being much more variable and altogether higher than that in the sea, is only tolerated by a limited group of species.

The experiments with fish larvae produced good evidence for the assumption that the weakest point of the culture technique used was the lack of controlled and sufficiently low temperature. It has been shown by Lebour (1925) that the critical stage in the life-history of the Angler was not, as might have been expected, directly the yolk sac was absorbed, but a few days afterwards, because for three days the fishes were catching food fast and eating it. In my experiments the Anglers and Herrings survived about 14 days after the yolk sac was absorbed, and the Pilchards 10 days, during which they fed and undoubtedly grew in size. But as the Herrings died 15 minutes after having been transferred into fresh medium. of a temperature $1-3^{\circ}$ higher than the original medium it cannot be surprising that the rest of them died within 2 weeks or so if exposed to slower but even bigger changes of room temperature. Both Herrings and Anglers kept under running tap water lived a few days longer than at room temperature, although when kept in the cellar the room temperature was considerably steadier than the temperature of the laboratory. The conclusion which may be drawn from these preliminary experiments is that fish-larvae need not only a steady but low temperature. Garstang (1900) concluded from experiments on the rearing of the "Butterfly Blenny" (Blennius ocellaris) "that the conditions which are most important for the healthy development of sea-fish larvae, and for the survival of a high percentage of fry through the critical stages of metamorphosis, are the following: (1) A liberal supply of pure water; (2) Mechanical, but moderate, agitation of the water . . ; (3) Provision of suitable food prior to the absorption of the yolk; and (4) A fairly constant, but not excessive supply of food each day. . . ." Point (4) appears to me of minor importance and low temperature should be included. Under controlled temperature conditions, with supply of the right food for the different stages, one would, I think, stand a fairly good chance of rearing fish larvae. It is one of the improvements of the culture technique which might also lead to a successful breeding of plankton copepods. Crawshay (1915) in experiments on the rearing of plankton copepods showed that temperature is a factor of the greatest importance and that "the daily fluctuations of air temperature to which uncovered vessels are exposed are liable to produce conditions that must sooner or later prove fatal to animals so sensitive to such changes." The best success - rearing of nauplii to the adult stage, with Nitzschia closterium as food-he obtained by keeping the culture vessels at a temperature with a varying range of no more than $1 \cdot 6^{\circ}$, a maximum daily variation of $1^{\circ}$, and an average temperature of $12 \cdot 3^{\circ}$. Clarke and Gellis (1935) kept copepods at different carefully controlled temperatures with Nitzschia 
closterium (from Dr. Allen's culture), Dunaliella, Carteria and Chlamydomonas as food. Under these conditions the majority of the copepods died after about two weeks. But it is possible that those forms were too large since certain experiments "indicate that bacteria and other constituents of the nannoplankton may be an important food for copepods in the sea."

I am grateful to Mr. F. S. Russell, Dr. S. Kemp, F.R.S., and Dr. E. J. Allen, F.R.S., for kindly reading and correcting the manuscript of this paper and giving much helpful advice.

\section{SUMMARY.}

The methods are described which made possible the establishment of pure cultures of a number of centric plankton diatoms and of the dinoflagellate Prorocentrum micans.

By means of a modified technique cultures were obtained of some nannoplankton autotroph flagellates varying in size from 2 to $10 \mu$. Attention is drawn to their great number in the plankton and to their importance as food in the sea.

Herring, Angler and Pilchard larvae were reared for respectively 27, 29 and 15 days after hatching. The young Herrings and Pilchards fed on Chlamydomonas sp. and Prorocentrum, the Anglers on nauplii of Artemia salina. Some evidence is given for the conclusion that the ultimate failure in rearing these species was caused by too high and variable temperatures.

\section{LITERATURE.}

Allen, E. J. 1914. On the Culture of the Plankton Diatom Thalassiosira gravida Cleve, in Artificial Sea-water. Journ. Mar. Biol. Assoc., N.S., Vol. X, 417-39.

Allen, E. J., and Nelson, E. W. 1910. On the Artificial Culture of Marine Plankton Organisms. Ibid., Vol. VIII, 421-74.

Álvik, G. 1934. Plankton-Algen norwegischer Austernpollen. I. Vorkommen und Systematik der Arten. Bergens Museum Arbok, 1934. Naturv. rekke, Nr. 6. II. Licht und Assimilation in verschiedenen Tiefen. Ibid., 1934, Naturv. rekke, Nr. 10.

Belar, K. 1928. Untersuchung der Protozoen. Methoden der wissenschaftl. Biologie. Springer, Berlin.

Clarke, G. L., and Gellis, S. S. 1935. The nutrition of copepods in relation to the food cycle of the sea. Biol. Bull., Vol. 68, 231-46. 
Crawshay, L. R. 1915. Notes on Experiments in the Keeping of Plankton Animals under Artificial Conditions. Journ. Mar. Biol. Assoc., N.S., Vol. X, 555-76.

Föyn, B. 1934. Lebenszyklus, Cytologie und Sexualität der Chlorophycee Cladophora Suhriana Kützing. Arch. Protistenk., Bd. 83, $1-56$.

—— 1934. Lebenszyklus und Sexualität der Chlorophycee Ulva lactuca L. Ibid., Bd. 83, 154-77.

GaARder, T. 1932. Untersuchungen über Produktions-und Lebensbedingungen in norwegischen Austern-Pollen. Bergens Museums Arbok, 1932. Naturv. rekke, Nr. 3.

—. 1933. Austernzucht in Norwegen. Chemisch-biologische Untersuchungen in norwegischen Austernpollen. Int. Rev. ges. Hydrobiol., Bd. 28, 250-61.

GaARder, T., and Spärck, R. 1932. Hydrographisch-biochemische Untersuchungen in norwegischen Austern-Pollen. Bergens Museums Arbok, 1932. Naturv. rekke, Nr. 1.

Garstang, W. 1900. Preliminary Experiments on the Rearing of SeaFish Larvae. Journ. Mar. Biol. Assoc., N.S., Vol. VI, 70-93.

Gross, F. 1932. Untersuchungen über die Polyploidie und die Variabilität bei Artemia salina. Naturwissenschaften, Bd. 20, 962-67.

—. 1934. Zur Biologie und Entwicklungsgeschichte von Noctiluca miliaris. Arch. Protistenk., Bd. 83, 178-96.

HämmerLing, J. 1934. Über die Geschlechtsverhältnisse von Acetabularia mediterranea und Acetabularia Wettsteinii. Ibid., Bd. 83, 57-97.

HaRdy, A. C. 1924. The Herring in Relation to its Animate Environment. I. Min. Agric. Fish., Fish. Invest., Ser. II, Vol. VI, No. 3, $1-53$.

Hartmann, M. 1928. Praktikum der Protozoologie. Jena.

Hartmann, M., und Huth, W. 1936. Untersuchungen über Geschlechtsbestimmung und Geschlechtsumwandlung von Ophryotrocha puerilis. Zool. Jahrb., Abt. allg. Zool., Bd. 56, 389-439.

Lebour, M. V. 1925. Young Anglers in Captivity and some of their Enemies. Journ. Mar. Biol. Assoc., N.S., Vol. XIII, 721-34.

Pringsheim, E. G. 1924. Algenkultur. Abderhalden's Handb. biol. Arbeitsmethoden, Abt. XI, Teil 2, 377-406. 
RüHmekoRf, T. 1935. Morphologie, Teilung und Hungerformen von Keronopsis. Arch. Protistenk., Bd. 85, 255.

Schreiber, E. 1927. Die Reinkultur von marinem Phytoplankton und deren Bedeutung für die Erforschung der Produktionsfähigkeit des Meerwassers. Wissensch. Meeresunters. Helgoland, N.F., 10, Nr. 10, 1-34.

Shen, T. H. 1936. Beiträge zum Studium der Geschlechtsbestimmung bei Dinophylus apatris. Zool. Jahrb., Abt. allg. Zool., Bd. 56, 219-38. 